\title{
ANALISIS EKONOMI ALAT PENANGKAPAN IKAN ARAD DI PANTAI UTARA PROVINSI JAWA TENGAH
}

\section{An Economic Analysis of 'Arad' Fishing Gear In the North Coast of Central Java Province}

\author{
*Benny Osta Nababan, Tridoyo Kusumastanto, \\ Luky Adrianto, dan Achmad Fahrudin \\ IPB University \\ JI. Raya Dramaga Kampus, IPB Dramaga Bogor, 16680 Jawa Barat, Indonesia \\ Diterima tanggal: 27 Desember 2019; Diterima setelah perbaikan: 8 April 2020; \\ Disetujui terbit: 30 Juni 2020
}

\begin{abstract}
ABSTRAK
Arad termasuk dalam kelompok alat penangkapan ikan yang dilarang berdasarkan Peraturan Menteri Kelautan dan Perikanan Republik Indonesia Nomor. 2/Permen-Kp/2015 tentang larangan penggunaan alat penangkapan ikan pukat hela (traw/s) dan pukat tarik (seine nets) di wilayah pengelolaan perikanan negara Republik Indonesia. Penelitian ini bertujuan untuk mengkaji secara ekonomi alat penangkapan ikan arad dengan yang dikombinasikan dengan alat penangkapan ikan lainnya di Pantai Utara Jawa Tengah. Jenis data yang digunakan adalah data primer dan data sekunder. Pengumpulan data primer dilakukan melalui wawancara kepada nelayan arad yang menggunakan kapal berukuran kurang dari 10 GT dengan menggunakan panduan wawancara serta pengamatan lapangan. Pengumpulan data sekunder dilakukan ke instansi pemerintah seperti Dinas Kelautan dan Perikanan Jawa Tengah dan BPS. Metode analisis data yang digunakan adalah analisis kelayakan usaha. Hasil penelitian menunjukan bahwa sebagian nelayan arad memiliki alat penangkap ikan lain seperti sudu, gillnet dan trammel net. Penggunaan alat penangkapan ikan berdasarkan musim ikan, seperti musim cumi, teri, kakap, belanak, kembung dan lainnya. Penelitian ini mengelompokkan nelayan berdasarkan jumlah alat penangkapan ikan yang dimiliki yaitu satu alat penangkapan ikan (arad), dua alat penangkapan ikan (arad dan sudu), tiga alat penangkapan ikan (arad, trammel net dan gillnet). Nelayan yang memiliki alat penangkapan ikan tambahan selain arad memperoleh keuntungan yang lebih tinggi dibandingkan hanya memiliki satu alat penangkapan ikan (arad). Kombinasi alat penangkapan ikan yang ramah lingkungan adalah menggunakan 3 alat penangkapan ikan yaitu arad, gillnet dan trammel net sesuai musim ikan memberikan manfaat ekonomi yang lebih tinggi dibandingkan dengan penggunaan arad sepanjang tahun.
\end{abstract}

Kata Kunci: alat penangkapan ikan 'arad'; analisis ekonomi; keberlanjutan; sumber daya ikan; kesejahteraan nelayan; Jawa Tengah

\begin{abstract}
Arad is an abandoned fishing gear based on the Regulation of the Minister of Maritime Affairs and Fisheries of the Republic of Indonesia Number 2 / Permen-Kp / 2015 concerning the prohibition on the use of trawls and seine nets in the territory of the Republic of Indonesia fisheries management. This study aimed at economic analysis of Arad capture fisheries (1 tool) compared with the capture using combination of Arad and other fishing equipment on the North Coast of Central Java. The study used primary and secondary data that were collected in the North Coast of Central Java. Primary data were collected through interviews and observation with Arad fishers working on boat under $10 \mathrm{GT}$. Secondary data were collected from government agencies such as Marine and Fisheries Agency of Central Java and Statistics Indonesia. The results showed that some of the Arad fishers had other fishing gear such as blade, gillnet and trammel net. The use of fishing gear depended on fish season, such as squid, anchovies, snapper, mullet, bloating and others. This study classified fishers based on the number of fishing gear that fisher's had, namely, one fishing gear (arad), two fishing gear (arad and blade), three fishing gear (arad, trammel net and gillnet). Fishers having additional fishing gear get higher profits compared to those having only one fishing gear (ARAD). The use of 3 fishing gear namely arad, gillnet and trammel net according to fish season provides higher economic benefits compared to Arad only throughout the year.
\end{abstract}

Keywords: 'arad', economic analysis; sustainability; fish resources; the welfare of fisher's; Jawa Tengah 


\section{PENDAHULUAN}

Perairan Laut Utara Jawa merupakan salah satu sumber daya yang bersifat common pool resource sehingga dalam pemanfaatannya tidak terdapat hak kepemilikan yang teridentifikasi secara jelas. Pemanfaatan sumber daya perikanan tangkap di Laut Jawa telah terindikasi mengalami fenomena tragedy of the common (Mc Elroy, 1991a) karena dalam pemanfaatannya telah melebihi kapasitas sumber daya perikanan akibat banyaknya armada penangkapan, dan juga pelarangan penggunaan trawl tahun 1980 semakin memberikan tekanan yang signifikan (Mc Elroy, 1991b). Fauzi \& Anna (2010) mengkaji mengenai daerah pesisir Laut Utara Jawa yang telah mengalami kondisi tekanan sumber daya yang cukup besar akibat banyaknya armada penangkapan. Kajian tersebut dilakukan dengan membandingkan keadaan perikanan sebelum era 1999 yang berorientasi pada pertumbuhan ekonomi dan berimplikasi terhadap penurunan stok sumber daya ikan, lalu diterapkan penghapusan alat penangkapan ikan pukat harimau (trawl) untuk kelestarian sumber daya ikan. Namun setelah era 1999 dengan sistem pemerintahan yang bersifat desentralitatif justru menambah rumitnya permasalahan, melalui otonomi daerah, semakin diberi peluang untuk mengeksploitasi sumber daya melalui perizinan. Kondisi yang telah dikaji tersebut, diperburuk dengan bertambahnya penggunaaan alat penangkapan ikan kurang ramah lingkungan dan tidak adanya kontrol sumber daya ikan yang sesuai. Seiring dengan perkembangan zaman, penggunaan alat penangkapan ikan yang dimodifikasi dan berteknologi canggih juga semakin berkembang. Akibatnya pemanfaatan Laut Utara Jawa tidak terkendali dan berakibat terjadi pemanfaatan berlebih. Dampak dalam jangka panjang yaitu deplesi sumber daya yang menuju tingkat over eksploitasi sumber daya dan akan mempengaruhi aktivitas serta pendapatan nelayan pesisir Laut Utara Jawa.

Potensi sumber daya ikan di Wilayah Pengelolaan Perikanan (WPP) 712 sebesar 1.341.632 ton/tahun. Potensi ikan terbesar adalah ikan demersal sebesar 657.525 ton/tahun dengan jumlah tangkapan yang diperbolehkan (JTB) sebesar 226.020 (80\% dari potensi) sedangkan tingkat pemanfaatan sebesar 0,83 yang artinya sudah di atas JTB. Secara rinci estimasi potensi, jumlah tangkapan yang diperbolehkan (JTB), dan tingkat pemanfaatan sumber daya ikan di WPP 712 disajikan dalam Tabel 1. Tingkat pemanfaatan sumber daya perikanan di WPP 712 menunjukkan telah terjadi eksploitasi secara berlebihan sehingga upaya penangkapan harus dikurangi, tingkat pemanfaatan dari 0,8 sampai 1 menunjukkan eksploitasi telah dilakukan secara penuh dimana upaya penangkapan dipertahankan dengan pengawasan yang ketat dan tingkat pemanfaatan dibawah 0,8 menunjukkan eksploitasi masih rendah atau moderate dimana upaya penangkapan masih dapat ditambah. Tingkat pemanfaaatan over eskploitasi antara lain perikanan pelagis besar, udang penaeid, lobster, kepiting, rajungan dan cumi-cumi (KKP, 2016).

Tabel 1. Estimasi Potensi, Jumlah Tangkapan yang Diperbolehkan (JTB), dan Tingkat Pemanfaatan Sumber daya Ikan di WPP 712.

Table 1. Estimation of Potential, Allowable Catch and Exploitation Rate of Fish in WPP 712.

\begin{tabular}{llrrc} 
No & $\begin{array}{c}\text { Jenis Perikanan/ } \\
\text { Fisheries Type }\end{array}$ & $\begin{array}{c}\text { Potensi/ Potential } \\
\text { (ton/tahun) }\end{array}$ & $\begin{array}{c}\text { JTB/ Allowable } \\
\text { catch (ton/tahun) }\end{array}$ & $\begin{array}{c}\text { Tingkat Pemanfaatan/ } \\
\text { Exploitation Rate }\end{array}$ \\
\hline 1 & Pelagis kecil/ Small pelagic & $364,663.00$ & $291,730.00$ & 0.38 \\
2 & Pelagis besar/ Large pelagic & $72,812.00$ & $58,250.00$ & 0.63 \\
3 & Ikan Demersal/Demersal & $657,525.00$ & $526,020.00$ & 0.83 \\
4 & Ikan Karang/Reef fish & $29,951.00$ & $23,961.00$ & 1.22 \\
5 & Udang Penaeid/Shrimp & $57,963.00$ & $46,372.00$ & 1.11 \\
6 & Lobster/ Lobster & 989.00 & 791.00 & 1.36 \\
7 & Kepiting/Crab & $7,664.00$ & $6,131.00$ & 0.70 \\
8 & Rajungan/ Small crap & $23,508.00$ & $18,806.00$ & 0.65 \\
9 & Cumi-cumi/Squid & $126,554.00$ & $101,244.00$ & 2.02 \\
& Jumlah/Total & $\mathbf{1 , 3 4 1 , 6 3 2 . 0 0}$ & $\mathbf{1 , 0 7 3 , 3 0 5 . 0 0}$ & \\
\hline
\end{tabular}

Sumber : KKP (2016)/Source: Ministry of Marine Affairs and Fisheries (2012) 
Beberapa alat penangkapan ikan yang sering digunakan di daerah Laut Utara Jawa misalnya payang (large net), dogol, jaring arad, pukat pantai (beach seine), jaring insang hanyut (drift gill net), jaring klitik (entangled gill net), insang tetap (set gill net), cantrang (demersal danish seine), pancing dan perangkap (trap). Jenis armada yang banyak digunakan nelayan di perairan Laut Utara Jawa adalah motor tempel, kapal motor dan kapal besar (Diniah, 2008). Pengawasan yang ketat terhadap peningkatan upaya penangkapan salah satunya dengan pelarangan alat penangkapan ikan arad yang diindikasikan sebagai trawl dan spesies targetnya adalah ikan demersal. Penelitian yang dilakukan Rowandi (2011), alat penangkapan ikan arad merupakan pukat hela, dapat berupa beam trawl (pukat hela dasar berpalang) maupun otter trawl (pukat hela dasar berpapan). Pukat hela baik beam trawl maupun otter trawl merupakan alat penangkapan ikan yang dilarang oleh Kementerian Kelautan dan Perikanan (KKP, 2015; 2016). Berkaitan dengan keluarnya regulasi tersebut maka setiap penggunaan alat penangkapan ikan perikanan yang dilarang menjadi kategori perikanan ilegal. Hal ini sebagaimana diungkapkan Xue (2003) dan Balton (2004), bahwa illegal fishing mengakibatkan kerusakan sumber daya ikan dan hilangnya potensi ekonomi masyarakat nelayan. Implikasi jangka panjang dari pelarangan alat penangkapan ikan ilegal diasumsikan akan membuat nelayan kembali sejahtera karena ikan-ikan lebih banyak lagi yang dapat tertangkap.

Ermawati \& Zuliyati (2015), mengungkapkan bahwa pelarangan pukat hela dan pukat tarik mengakibatkan pengangguran, penurunan kesejahteraan, dan kejahatan. Selain itu, Sukandar et al. (2015) menyatakan bahwa larangan pukat hela dan pukat tarik di Pantai Utara Jawa telah mengakibatkan penurunan hasil tangkapan sebesar $30 \%$. Penelitian yang dilakukan oleh Nababan, Kusumastanto, Adrianto \& Fahrudin (2020a) mengungkapkan penolakan terhadap PerMen KP 71/2016 oleh para nelayan pukat tarik (cantrang) terjadi karena berdampak pada penurunan kesejahteraan nelayan. Perikanan demersal merupakan perikanan yang berumur pendek yang jika tidak dimanfaatkan akan mati secara alamiah (Budiman 2006; Ernawati 2007). Sumber daya perikanan termasuk dalam ketegori sumber daya yang dapat diperbaharui (pulih), dimana ketersediaan sumber daya di masa yang akan datang sangat tergantung pada tingkat pemanfaatan yang dilakukan saat ini (Rees 1990). Menurut Haynes, Geen \& Wilks (1986), pengelolaan sumber daya perikanan dapat meningkatkan benefit bagi pelaku perikanan melalui tiga cara. Pertama, meningkatkan output dengan mengelola stok ikan pada kondisi maksimum penangkapan dalam jangka panjang, kedua menurunkan biaya per unit penangkapan dengan mengurangi persaingan antar pelaku penangkapan ikan, ketiga, meningkatkan keuntungan per unit output yang dihasilkan. Oleh karena itu, perikanan tetap harus dimanfaatkan dan dikelola dengan optimal karena jika dibiarkan maka perikanan yang mati secara alamiah menjadi biaya korbanan terhadap suatu aset yang hilang. Analisis jangka panjang seperti NPV, Net B/C dan IRR dapat digunakan untuk mengetahui benefit dan biaya pemanfaatan sumber daya perikanan. Analisis tersebut memberikan gambaran tentang manfaat yang diperoleh dalam ekpsloitasi sumber daya perikanan, sehingga dapat ditarik kesimpulan apakah eksploitasi tersebut memberikan manfaat yang optimal.

\section{METODOLOGI}

Penelitian dilakukan di Pantai Utara Jawa Provinsi Jawa Tengah yang termasuk dalam wilayah pengelolaan perikanan 712 . Data yang digunakan dalam penelitian ini terdiri dari data primer dan data sekunder. Analisis ekonomi dalam penelitian ini dilakukan melalui 2 pendekatan analisis yakni analisis kualitatif dan kuantitatif. Analisis kualitatif dilakukan untuk memperoleh gambaran tentang usaha sedangkan analisis kuantitatif meliputi analisis kelayakan usaha dengan menggunakan perhitungan kriteria-kriteria investasi yaitu Net Present Value (NPV), Net Benefit Cost Ratio (Net B/C), Internal Rate of Return (IRR) (Gittinger, 1986).

\section{Lokasi dan Waktu Penelitian}

Penelitian dilakukan di Provinsi Jawa Tengah yang meliputi kabupaten-kabupaten pesisir pantai utara Jawa. Pemilihan lokasi ini karena banyaknya nelayan yang mengoperasikan alat penangkapan ikan arad seperti Kabupaten Demak, Rembang dan Kendal. Perbedaan kelompok alat penangkapan ikan tidak dibedakan berdasarkan lokasi. Setiap lokasi memiliki dua atau tiga kelompok tersebut. Penelitian dilakukan mulai bulan Juli sampai dengan Oktober tahun 2019. 


\section{Jenis dan Metode Pengambilan Data}

Data yang digunakan dalam penelitian ini terdiri dari data primer dan data sekunder. Jumlah populasi nelayan arad tidak diketahui dengan pasti, karena alat penangkapan ikan tersebut merupakan alat penangkapan ikan yang dilarang berdasarkan peraturan menteri Kelautan dan Perikanan. Data primer diperoleh dari hasil diskusi kelompok terfokus (Focus Group Discussion/FGD) dengan perwakilan nelayan yang berasal dari Kabupaten Demak, Rembang dan Kendal. Pengumpulan data primer juga dilakukan dengan wawancara mendalam dengan tokoh kunci seperti ketua kelompok nelayan, dan stakeholder terkait. Peserta FGD adalah perwakilan nelayan yang melakukan penangkapan ikan di Pantai Utara Jawa dengan menggunakan alat penangkapan ikan arad dan alat penangkapan ikan modifikasi arad, serta nelayan yang memiliki alat penangkapan ikan tambahan selain arad. Total jumlah responden dalam penelitian adalah 32 orang yang merupakan informan kunci (key person) tersebar di 3 kabupaten tersebut. Data sekunder yang digunakan berasal dari pelabuhan perikanan, Dinas Perikanan dan Kelautan Kabupaten, Dinas Perikanan dan Kelautan Provinsi Jawa Tengah, dan Kementerian Kelautan dan Perikanan.

\section{Metode Analisis Data}

Metode analisis data terkait dengan analisis ekonomi yang dilakukan melalui 2 pendekatan analisis yakni analisis kualitatif dan kuantitatif. Analisis kualitatif dilakukan untuk memperoleh gambaran tentang usaha penangkapan sedangkan analisis kuantitatif meliputi analisis kelayakan usaha dengan menggunakan perhitungan kriteriakriteria investasi yaitu Net Present Value (NPV), Net Benefit Cost Ratio (Net B/C), Internal Rate of Return (IRR) (Gittinger, 1986).

Penghitungan analisis aspek finansial memerlukan kriteria investasi yang dapat digunakan untuk menyatakan layak atau tidaknya suatu usaha. Kriteria investasi yang digunakan yaitu Net Present Value (NPV), Net Benefit Cost Ratio (Net B/C), dan Internal Rate of Return (IRR). Analisis kelayakan investasi dilakukan dengan terlebih dahulu menyusun aliran tunai diskontokan (discounted cashflow) karena adanya pengaruh waktu terhadap nilai uang atau semua biaya dan manfaat yang akan datang harus diperhitungkan.

\section{a). Net Present Value (NPV)}

Net Present Value dapat diartikan sebagai nilai sekarang dari arus pendapatan yang ditimbulkan oleh investasi. NPV menunjukkan keuntungan yang akan diperoleh selama umur investasi atau merupakan jumlah nilai penerimaaan arus tunai pada waktu sekarang dikurangi dengan biaya yang dikeluarkan selama waktu tertentu. Rumus yang digunakan dalam perhitungan NPV adalah sebagai berikut:

$$
N P V=\sum_{t=0}^{n} \frac{B_{t}-C_{t}}{(1+i)^{t}}
$$

Keterangan/Remaks

$\mathrm{B}_{\mathrm{t}} \quad=$ Penerimaan tahun ke-t $(\mathrm{Rp}) /$ Benefit yeart $(/ I D R)$

$\mathrm{C}_{\mathrm{t}} \quad=$ Biaya tahun ke-t $(\mathrm{Rp}) /$ Cost yeart $($ IDR)

$\mathrm{n}=$ Umur proyek (Tahun)/Time period (Year)

$\mathrm{i} \quad=$ Tingkat suku bunga(\%)/Discount rate (\%)

$\mathrm{t}=$ Periode (Tahun)/Period (Year)

Dalam metode NPV terdapat tiga penilaian investasi, yaitu :

1. NPV $\geq 0$ layak/ feasible: berarti secara finansial usaha layak untuk dilaksanakan karena manfaat yang diperoleh lebih besar dari biaya.

2. NPV = 0 impas/break even, berarti secara finansial usaha berada pada kondisi break even karena manfaat yang diperoleh sama dengan biaya yang dikeluarkan.

3. NPV $\leq 0$ tidak layak/ not feasible, berarti secara finansial usaha tersebut tidak layak untuk dilaksanakan, hal ini dikarenakan manfaat yang diperoleh lebih kecil dari biaya/tidak cukup untuk menutup biaya yang dikeluarkan.

\section{b). Net Benefit Cost Ratio (Net B/C)}

Net B/C ratio merupakan angka perbandingan antara nilai kini arus manfaat dibagi dengan nilai sekarang arus biaya. Angka tersebut menunjukkan tingkat besarnya tambahan manfaat pada setiap tambahan biaya sebesar satu satuan uang. Kriteria yang digunakan untuk pemilihan ukuran Net B/C ratio dari manfaat proyek adalah memilih semua proyek yang nilai Net B/C rasionya sebesar satu atau lebih jika manfaat didiskontokan pada tingkat biaya opportunity capital, tetapi jika nilai $\mathrm{Net} \mathrm{B} / \mathrm{C}<1$, maka proyek tersebut tidak layak untuk dilaksanakan (Gittinger, 1986). Rumus yang digunakan sebagai berikut: 


$$
\text { Net } B / C=\frac{\sum_{t=0}^{n} \frac{B_{t}-C_{t}}{(1+i)} \text { untuk } B_{t}-C_{t}>0}{\sum_{t=0}^{n} \frac{B_{t}-C_{t}}{(1+i)^{t}} \text { untuk } B_{t}-C_{t}<0}
$$

\section{Keterangan/Remaks}

Net $B / C=$ Nilai rasio penerimaan-biaya/Benefit-cost ratio

Bt $=$ Penerimaan pada tahun ke $\mathrm{t} /$ Benefit year $t$

$\mathrm{C}_{\mathrm{t}} \quad=$ Biaya tahun ke-t (Rp)/Cost yeart $($ IDR)

$\mathrm{n} \quad=$ Umur proyek (Tahun)/Time period (Year)

$\mathrm{i} \quad=$ Tingkat suku bunga(\%)/Discount rate (\%)

$\mathrm{t}=$ Periode $($ Tahun $) /$ Period (Year)

\section{c). Internal Rate of Return (IRR)}

Internal Rate Return adalah nilai discount rate yang membuat NPV dari suatu proyek/ usaha sama dengan nol. Internal Rate of Return adalah tingkat rata-rata keuntungan intern tahunan dinyatakan dalam satuan persen. Jika diperoleh nilai IRR lebih besar dari tingkat diskonto yang berlaku, maka proyek/usaha layak untuk dilaksanakan. Sebaliknya jika nilai IRR lebih kecil dari tingkat diskonto yang berlaku maka proyek/ usaha tersebut tidak layak untuk dilaksanakan. Rumus yang digunakan dalam menghitung IRR adalah sebagai berikut:

$$
I R R=i_{1}+\frac{N P V_{1}}{\left(N P V_{1}-N P V_{2}\right)}\left(i_{2}-i_{1}\right)
$$

Keterangan/Remaks

$\mathrm{NPV}_{1}=\mathrm{NPV}$ yang bernilai positif (Rp)/Positive NPV (IDR) $\mathrm{NPV}_{2}=\mathrm{NPV}$ yang bernilai negatif/ Negative NPV (Rupiah)

$\mathrm{i}_{1} \quad$ = Tingkat bunga yang menghasilkan NPV positif (\%)/ Discount rate at positive NPV(\%)

$\mathrm{i}_{2} \quad=$ TingkatbungayangmenghasilkanNPVnegatif $(\%) /$ Discount rate at negative NPV (\%)

\section{HASIL DAN PEMBAHASAN}

\section{Karakteristik Perikanan di Jawa Tengah}

Provinsi Jawa Tengah yang terletak pada $5^{0} 4^{\prime}$ LS - $8^{\circ} 30^{\prime}$ LS dan $108^{\circ} 30^{\prime}$ BT - 111 $30^{\prime}$ BT, memiliki wilayah seluas $32.284,268 \mathrm{~km} 2$ atau sekitar $23,97 \%$ luas wilayah Pulau Jawa. Potensi geografis sumber daya Kelautan dan Perikanan di Jawa Tengah meliputi 8 buah pulau dan 37 buah pulau-pulau kecil, yang tersebar di Laut Jawa sebanyak 35 Pulau dan 10 pulau di Samudera Hindia yaitu Pulau Nusakambangan. Dari 45 buah pulau tersebut, hanya 30 buah yang memiliki nama sedangkan 15 buah pulau belum diberikan nama.
Di samping itu, Jawa Tengah memiliki panjang garis pantai $791,76 \mathrm{~km}$ yang terdiri dari pantai utara $289,07 \mathrm{~km}$, dan pantai selatan $502,69 \mathrm{~km}$. (DKP Jawa Tengah, 2017). Provinsi Jawa Tengah diapit oleh tiga provinsi yaitu Provinsi Jawa Timur di sebelah timur, Provinsi Jawa Barat di sebelah barat dan Provinsi Daerah Istimewa Yogyakarta (DIY) di sebelah selatan. Di sepanjang pantai utara Jawa Tengah terletak beberapa kabupaten/kota dari bagian timur hingga barat adalah Kabupaten Rembang, Kabupaten Pati, Kabupaten Jepara, Kabupaten Demak, Kota Semarang, Kabupaten Kendal, Kabupaten Batang, Kota Pekalongan, Kabupaten Pekalongan, Kabupaten Pemalang, Kabupaten Tegal, Kota Tegal, dan Kabupaten Brebes. Kondisi pantai utara Jawa Tengah yang landai dan perairan yang relatif tenang menjadikan pantai utara Jawa Tengah sebagai daerah yang memiliki cukup banyak sentra nelayan dan penangkapan ikan terutama dengan skala kecil dan menengah, namun saat ini kondisinya sudah padat tangkap. Kondisi ini terlihat dari rata-rata tingkat pemanfaatan sumber daya perikanan laut di Laut Jawa sebesar 99\% (KKP, 2013).

Perikanan tangkap Provinsi Jawa Tengah terdiri dari perikanan tangkap laut dan perikanan tangkap perairan umum yang mempunyai potensi untuk dikembangkan. Potensi perikanan tangkap laut yang tersebar di perairan Jawa Tengah sekitar 1.873 .530 ton/tahun meliputi Laut Jawa sekitar 796.640 ton/ tahun dan Samudera Indonesia sekitar 1.076 .890 ton/tahun (Naya, Wijayanto \& Sardiyatmo, 2017).

Ditinjau dari ukuran armada penangkapan ikan yang digunakan oleh nelayan di Jawa Tengah bagian utara didominasi oleh armada motor tempel yang berukuran kurang dari 5 GT (Tabel 2) dan jumlah terbanyak berikutnya ukuran 5-10 GT. Kapal penangkapan ikan dengan bobot mati lebih dari 30 GT hanya sebagian kecil dari jumlah kapal di Jawa Tengah (Dinas Kelautan dan Perikanan Provinsi Jawa Tengah, 2016). Jumlah kapal perikanan terbesar di Kabupaten Rembang. Tempat berlabuh kapal yang berukuran lebih dari 30 GT hanya di PPN Pekalongan dan PPP Klidang Lor (Triarso, 2012). Alat penangkapan ikan yang digunakan nelayan dengan ukuran kapal kurang dari 5 GT antara lain dogol, payang, cantrang dan arad. Pada tahun 2016, 25\% dari total unit alat penangkapan ikan di Jawa Tengah terdiri dari alat penangkapan ikan yang tergolong pukat tarik. Target utama tangkapan pukat tarik adalah udang dan ikan demersal. Habitat udang 
adalah daerah estuaria yang memiliki banyak masukan massa air tawar dan air laut atau sangat dipengaruhi oleh proses pasang-surut dengan tipe substrat terdiri dari lumpur dan pasir serta banyak serasah (Hedianto, Purnamaningtyas \& Riswanto, 2014). Habitat tersebut tidak jauh dari pantai, jadi untuk melakukan penangkapan udang, nelayan tidak memerlukan armada penangkapan yang besar karena fishing ground dekat. Tingginya jumlah armada penangkapan di daerah estuaria menyebabkan padatnya penangkapan ikan di perairan pantai.

Produksi perikanan di Jawa Tengah didominasi oleh perikanan pelagis kecil dan demersal. Total produksi pada tahun 2017 adalah 319 ribu ton (Tabel 3). Berdasarkan pada Tabel 1, jumlah tangkapan ikan yang diperbolehkan di WPP 712 adalah 785 ribu ton, dengan demikian Provinsi Jawa Tengah memanfaatkan ikan di WPP 712 sebesar 40,6\% dari jumlah tangkapan yang diperbolehkan (JTB). Produksi ikan tertinggi berasal dari Kota Tegal, hal ini disebabkan karena banyaknya kapal perikanan yang berukuran lebih dari 10 GT yang mendaratkan ikan hasil tangkapan. Produksi ikan demersal 107.276 ton pada tahun 2017.

\section{Karakteristik Perikanan Jaring Arad}

Menurut Indrawasih \& Wahyono (2009), alat penangkapan ikan arad merupakan jenis alat penangkapan ikan yang tidak ada penggantinya bagi nelayan pantura karena biaya pembuatan

Tabel 2. Jumlah Kapal Perikanan menurut Ukuran di Provinsi Jawa Tengah, 2017.

Table 2. Number of Fishing Vessel by Tonase in Central Java, 2017.

\begin{tabular}{|c|c|c|c|c|c|c|c|c|c|}
\hline \multirow{2}{*}{$\begin{array}{c}\text { Kabupaten/ Kota/ } \\
\text { Regency }\end{array}$} & \multicolumn{3}{|c|}{$\begin{array}{c}\text { Motor Tempel/ } \\
\text { Outboard Motor Boat (GT) }\end{array}$} & \multicolumn{6}{|c|}{ Kapal Motor/Motor Boat (GT) } \\
\hline & $<5$ & $5-10$ & $10-30$ & $<5$ & $5-10$ & $10-30$ & $30-50$ & $50-100$ & $100-200$ \\
\hline Brebes & 1,216 & 443 & 211 & 1 & 148 & 144 & & & \\
\hline Tegal & 612 & & 108 & & & & & & \\
\hline Kota Tegal & 165 & 157 & & & & 485 & 88 & 45 & \\
\hline Pemalang & 654 & 444 & & & 156 & 186 & 2 & & \\
\hline Pekalongan & 325 & 10 & & 28 & 30 & & 5 & & \\
\hline Kota Pekalongan & & & & & 83 & 139 & 3 & 33 & 3 \\
\hline Batang & 511 & & & & 141 & 48 & 8 & 9 & \\
\hline Kendal & 883 & 311 & 418 & & 26 & & & & \\
\hline Kota Semarang & 978 & 30 & & & & & & & \\
\hline Demak & 2,416 & 246 & 175 & & & & 2 & & \\
\hline Jepara & 2,156 & 504 & 108 & 699 & & & 2 & & \\
\hline Pati & 1,374 & & & & 20 & 329 & 78 & 186 & 32 \\
\hline Rembang & 2,646 & & 157 & & & 709 & 236 & & \\
\hline
\end{tabular}

Sumber: Dinas Perikanan dan Kelautan Provinsi Jawa Tengah, 2018/

Source: Fisheries and Maritime Agency of Central Java, 2018

Tabel 3. Jumlah Produksi menurut Kelompok Jenis Ikan di Jawa Tengah, 2017.

Table 3. Total Fish Production by Group of Fish in Central Java, 2017.

\begin{tabular}{|c|c|c|c|c|c|c|}
\hline $\begin{array}{c}\text { Kabupaten/ Kota } \\
\text { Regency }\end{array}$ & $\begin{array}{c}\text { Seluruh Ikan/ } \\
\text { All fish }\end{array}$ & $\begin{array}{l}\text { Pelagis Kecil/ } \\
\text { Small Pelagic }\end{array}$ & $\begin{array}{l}\text { Pelagis Besar } \\
\text { Large Pelagic }\end{array}$ & $\begin{array}{l}\text { Demersal/ } \\
\text { Demersal }\end{array}$ & $\begin{array}{l}\text { Ikan Karang/ } \\
\text { Reef Fish }\end{array}$ & $\begin{array}{l}\text { Binatang Berkulit } \\
\text { Keras/ Hard } \\
\text { Skinned Animals }\end{array}$ \\
\hline Brebes & 8,518 & 6,694 & 19 & 1,665 & 33 & 1 \\
\hline Tegal & 1,457 & 1,053 & 1 & 104 & & 299 \\
\hline Kota Tegal & 77,559 & 33,176 & 5,579 & 27,349 & 3,211 & 34 \\
\hline Pemalang & 29,184 & 13,068 & 1,451 & 12,503 & 535 & 1,169 \\
\hline Pekalongan & 5,257 & 2,526 & 385 & 2,059 & & 126 \\
\hline Kota Pekalongan & 19,872 & 16,252 & 2,865 & 622 & & 10 \\
\hline Batang & 27,281 & 8,658 & 1,988 & 15,472 & 10 & 205 \\
\hline Kendal & 1,472 & 10,088 & 46 & 400 & & \\
\hline Kota Semarang & 353 & 256 & 0 & 90 & & 6 \\
\hline Demak & 16,424 & 7,659 & 459 & 1,596 & & 6,263 \\
\hline Jepara & 7,804 & 62 & 47 & 7,686 & & 3 \\
\hline Pati & 54,489 & 42,149 & 1,691 & 8,679 & 1,804 & 44 \\
\hline Rembang & 70,037 & 29,157 & 5,932 & 29,052 & 4,521 & 201 \\
\hline Jumlah/Total & 319,706 & 170,799 & 20,462 & 107,276 & 10,113 & 8,361 \\
\hline
\end{tabular}


arad lebih murah dan tingkat kemampuannya untuk menjaring udang dan ikan-ikan demersal. Nababan, Solihin \& Christian (2018) menyatakan produktivitas alat penangkapan ikan dilarang ini (arad) memiliki nilai di atas $50 \mathrm{~kg}$ per setting dibandingkan alat penangkapan ikan ramah lingkungan yang berkisar $2 \mathrm{~kg}$ per setting sampai $20 \mathrm{~kg}$ per setting. Komposisi hasil tangkapan jaring arad di PPN Pekalongan berdasarkan jenis hasil tangkapannya didominasi oleh ikan petek (Leiognathus spp.) 13\%, cumi-cumi (Loligo spp.) $12 \%$, dan kuniran (Upeneus spp.) 11\%, selanjutnya ikan kurisi (Nemipterus spp.) 6\%, ikan beloso (Saurida spp.) 5\%, Pari (Dasyatis sp.) dan belong (Priacanthus) 4\% (Triharyuni \& Trihargiyatno, 2012).

Jenis alat penangkapan ikan yang digunakan oleh para nelayan Jawa Tengah adalah pukat tarik, pukat kantong, pukat cincin, jaring insang, jaring angkat, pancing, alat pengumpul, dan alat penangkapan ikan lainnya. Arad merupakan alat penangkapan ikan yang termasuk dalam kelompok pukat tarik seperti cantrang dan dogol. Jaring arad pada prinsipnya terdiri atas bagian kantong (cod end), badan (body), dan sayap (wing). Dimensi jaring arad di Asem Doyong secara umum memiliki panjang head rope $14 \mathrm{~m}$ dan ground rope $17 \mathrm{~m}$. Panjang sayap $7 \mathrm{~m}$ dengan besar mata jaring (mesh size) 2 inci. Panjang badan jaring $7 \mathrm{~m}$, besar mata jaring terdiri atas $2,13 / 4 ; 1,5 ; 11 / 4$; dan 1 inci. Panjang kantong jaring $2 \mathrm{~m}$ mesh size $3 / 4$ inci. Panjang tali selambar (warp) berkisar 150-200 m. Otter board terbuat dari papan berukuran 0,8x0,5 m (Ernawati \& Sumiono, 2010). Spesifikasi perahu dan alat penangkapan ikan arad di Tambak Lorok memiliki ukuran perahu 4-8 GT dengan kekuatan mesin 20 hingga $48 \mathrm{PK}$. Ukuran panjang kapal 8 $\mathrm{m}$, lebar 2,5 m dan kedalaman 1,3 m. Mesh size kantong rata-rata $24,5 \mathrm{~mm}$ atau 1 inch, mesh size badan 31,75 $\mathrm{mm}$ atau 1,25 inch sedangkan mesh size sayap sebesar 2 inch (Septiana, Saputra \& Gofur, 2019). Berdasarkan hasil penelitian(Ernawati \& Sumiono, 2010) dan (Septiana et al., 2019) serta hasil wawancara dengan nelayan Demak dan Kendal tidak terdapat perbedaan yang mencolok dalam penggunaan armada penangkapan pada tahun 2010 dan 2019, begitu juga dengan mesh size jaring yang digunakan.

Rata-rata laju tangkap trawl pada musim barat adalah 61,6 kg/jam (Ernawati, 2007). Jumlah hasil tangkapan tertinggi pada kedalaman 20-30 m yaitu 168,8 kg/jam dan tangkapan terendah pada kedalaman 41-50 m yaitu 39,2 kg/jam. Komposisi hasil tangkapan dominan adalah Leiognathidae, Synodontidae, Nemipteridae, dan Mullidae (Ernawati, 2007). Rata-rata hasil tangkapan jaring arad $123,14 \mathrm{~kg} /$ trip yang didominansi oleh hasil tangkapan sampingan yaitu kelompok ikan 58,7\%, non ikan $28,0 \%$, dan udang sebagai sasaran utama hanya 13,2\% (Ernawati \& Sumiono, 2010). Komposisi hasil tangkapan kelompok ikan per jenis didominansi oleh ikan beloso (Saurida spp.) 16\%, simping (Amusium pleuronectes) 11,8\%, blekutak (Sephia spp.) 11,5\%, dan petek (Leiognathus spp.) 9,1\% (Ernawati \& Sumiono, 2010).

Laju tangkap rata-rata kapal arad yang berbasis di Pekalongan tahun 1999-2006 sebesar $441,3 \mathrm{~kg} /$ trip. Rata-rata komposisi hasil tangkapan kapal arad tahun 2003-2006 didominasi oleh ikan petek (Leiognathus spp.) dengan persentase sebesar $13 \%$ kemudian cumi-cumi (Loligo spp.) 12\%, dan kuniran (Upeneus spp.) 11\% (Triharyuni \& Trihargiyatno, 2012)

Hasil tangkapan jaring arad terdiri dari 4 kelompok yaitu Krustacea, Moluska, Ikan dan Echinodermata. Krustasea meliputi kepiting (Scilla spp.), udang krosok (Metapenaeus lysianassa), udang ronggeng (Orastoquila oratoria), udang windu (Penaeus monodon), udang putih (Penaeus merguiensis), udang barat (Metapenaeus dobsoni), udang merah (Parapenaeus sp.), kelompok udang kecil, dan rajungan kecil. Moluska meliputi cumi-cumi (Loligo sp.), kerang darah (Anadara granosa), Sotong (Sepiela sp.), kelompok kerang kecil, keong, dan cumi - cumi kecil. Ikan meliputi barakuda (Sphyraena jello), bawal putih (pampus argentus), belanak (Valamugil speigieri), beloso (Saurida tumbil), giligan (Pennamicrodon), kembung (Rastrelliger kanagurta), peperek (Leiognathus sp.), tenggiri (Sromberomus commerson), teri (Stolephorus indicus), tigawaja (Nibea albifora). Echinodermata berupa kelompok bintang laut kecil (Septiana et al., 2019).

Ditinjau dari komposisi hasil tangkapan arad dari tahun 2007 (Ernawati, 2007), tahun 2010 (Ernawati \& Sumiono, 2010) dan tahun 2019 (Septiana et al., 2019) terlihat, komposisi hasil tangkapan mengalami perubahan. Jenis ikan yang ditangkap mengalami peningkatan seperti kembung, tenggiri, bawal dan tigawaja. Volume hasil tangkapan cumi-cumi mengalami peningkatan. Perubahan jenis ikan hasil tangkapan ini disebabkan karena adanya modifikasi terhadap alat penangkapan ikan arad yang digunakan. Arad yang umum digunakan saat ini dikenal dengan 
nama arad barongan dengan target hasil tangkapan bukan lagi udang, melainkan ikan demersal dan ikan pelagis yang berenang di kolom air dekat dengan permukaan.

\section{Analisis Ekonomi Jaring Arad}

Para nelayan arad yang masih beroperasi di perairan Jawa Tengah berharap Kementerian Kelautan dan Perikanan tidak melarang arad namun pembatasan seperti jumlah arad yang beroperasi, hari melaut, musim, atau wilayah penangkapan. Alasannya adalah saat penegakkan hukum dilakukan, nelayan mengalami ketakutan mengoperasikan arad, namun ikan dasar (demersal) di laut menjadi banyak sehingga kalau tidak ditangkap ikan-ikannya akan mati sendiri baik oleh predator alami maupun keterbatasan ruang/ kapasitas. Hal ini sama seperti yang disampaikan oleh Haynes et al. (1986), perikanan tetap harus dimanfaatkan dan dikelola dengan optimal karena jika dibiarkan maka perikanan yang mati secara alamiah menjadi biaya korbanan terhadap suatu aset yang hilang. Stok ikan harus dipertahankan pada tingkat yang berkelanjutan secara biologis (https://sustainabledevelopment.un.org/sdg14). Hal ini juga menunjukkan bahwa sumber daya ikan dapat dimanfaatkan sampai pada tingkat maximum sustainable yield (MSY) dan bukan tanpa pemanfaatan.

Analisis ekonomi perikanan skala kecil di Jawa Tengah dengan menganalisis usaha perikanan menggunakan alat penangkapan ikan arad dan alat penangkapan ikan lainnya yang digunakan. Penggunaan jaring arad oleh nelayan Jawa Tengah tersebar di Kabupaten Rembang, Jepara, Kendal, Batang, Tegal, Kebumen, Pati, Demak, Pemalang, Pekalongan dan Brebes (Indrawasih \& Wahyono, 2009).

Perahu yang digunakan nelayan rata-rata panjang 6,3 - 7,1 m, lebar 0,9-3,0 m, ke dalaman lambung $0,8-1,0 \mathrm{~m}$, bobot 3,5 - 4,0 GT , dengan mesin 16 - $20 \mathrm{PK}$, jaring arad panjang 20-21,5 $\mathrm{m}$, lebar 8-10 m mesh size jaring 1,9-2,5 cm, penangkapan hanya dilakukan 6-8 jam per hari atau biasa disebut one day fishing. Mayoritas tingkat pendidikan nelayannya tamat SD ( $\pm 81 \%)$, yang tidak tamat SD $( \pm 9 \%)$, SMP $( \pm 9 \%)$, dan $\operatorname{SLTA}( \pm 1 \%)$, dan bekerja sebagai nelayan rata-rata sudah 18 tahun (Sulistyowati, 2017).

Pada penelitian ini dibedakan nelayan menggunakan 1 jenis alat penangkapan ikan (arad), 2 jenis alat penangkapan ikan (arad dan sudu) dan 3 jenis alat penangkapan ikan (arad, trammel net dan gillnet). Alat penangkapan ikan utama yang digunakan adalah arad, yang lainnya sudu dan gillnet. Alat penangkapan ikan arad yang digunakan oleh nelayan Jawa Tengah dapat menangkap ikan demersal, ikan pelagis, udang dan cumi-cumi. Jenis alat penangkapan ikan ini juga telah mengalami modifikasi dari bentuk arad yang semula diperkenalkan. Alat ini merupakan pukat tarik dengan bukaan mulut yang sangat besar sehingga dapat menangkap semua jenis ikan yang dilewati. Penggunaan ini dibantu dengan mesin penarik sehingga dapat dioperasikan oleh 1 orang. Penangkapan dilakukan sepanjang tahun dengan lokasi penangkapan tidak jauh dari pantai.

Nelayan skala kecil di Pantai Utara Jawa Tengah sebagian besar menggunakan alat penangkapan ikan arad sebagai alat penangkapan ikan utama dalam melakukan usaha penangkapan. Nelayan skala kecil adalah nelayan yang melakukan penangkapan ikan untuk memenuhi kebutuhan hidup sehari-hari, baik yang tidak menggunakan kapal penangkap ikan maupun yang menggunakan kapal penangkap Ikan berukuran paling besar 10 (sepuluh) gros ton (GT). Investasi yang diperlukan nelayan dengan menggunakan alat penangkapan ikan arad antara lain, kapal, mesin dan alat penangkapan ikan. Kapal yang digunakan oleh nelayan berkekuatan kurang dari 5 GT dengan ukuran panjang berkisar 6-8 meter, lebar 1,5 meter dan kedalaman 1 meter. Mesin yang digunakan oleh nelayan berkisar 2 sampai 4 unit dengan kekuatan 16 dan 23 PK. Penggunaan jumlah mesin sesuai dengan kemampuan investasi yang dapat dilakukan oleh nelayan. Dengan menggunakan mesin lebih banyak maka nelayan dapat sampai ke lokasi penangkapan (fishing ground) lebih cepat, sedangkan pemilihan lokasi penangkapan berdasarkan pengalaman dan informasi keberadaan ikan dari aktivitas penangkapan sebelumnya.

Alat penangkapan ikan arad yang digunakan oleh nelayan merupakan alat penangkapan ikan yang diwarisi dari orang tua dengan melakukan modifikasi sesuai dengan perkembangan ketersediaan ikan yang dapat ditangkap. Alat penangkapan ikan arad yang berkembang saat ini yaitu arad dengan target tangkapan ikan demersal, cumi-cumi, kembung dan teri. Ketika musim teri, maka nelayan memberikan jaring tambahan di dalam arad supaya dapat menangkap teri yang mempunyai ukuran lebih kecil dibandingkan ikan target. 
Total biaya investasi awal yang diperlukan oleh nelayan dengan menggunakan 1 jenis alat penangkapan ikan adalah Rp38.000.000 dengan menggunakan 3 mesin berkekuatan 23 PK. Nelayan yang memiliki 2 jenis alat penangkapan ikan memerlukan investasi Rp39.500.000 dan nelayan dengan 3 alat penangkapan ikan memerlukan investasi Rp40.700.000 Jumlah investasi ini dapat lebih rendah ketika nelayan menggunakan jumlah mesin lebih sedikit dan dapat lebih tinggi ketika menggunakan mesin lebih banyak. Biaya operasional yang terbesar yang diperlukan nelayan yaitu untuk bahan bakar (solar). Biaya operasional lainnya yaitu biaya untuk pembelian oli, ransum dan perbaikan jaring. Oli yang digunakan oleh nelayan pada umumnya oli curah sedangkan oli untuk penambahan yang diberikan setiap 3 trip menggunakan oli bekas yang telah didaur ulang. Alat penangkapan ikan yang digunakan berupa jaring yang sangat rentan terhadap kerusakan, sehingga diperlukan biaya untuk perbaikan jaring. Kalau jaring arad sudah rusak parah, maka harus segera diganti. Nelayan memilih jaring arad sebagai alat penangkapan ikanan utama, karena harga alat penangkapan ikan tersebut lebih murah dibandingkan alat penangkapan ikan lainnya.

Total biaya operasional penangkapan selama 1 tahun dengan menggunakan 1 alat penangkapan ikan yaitu Rp103.138.000, dengan menggunakan 2 alat penangkapan ikan yaitu Rp117.258.000 dan dengan menggunakan 3 alat penangkapan ikan Rp69.179.000. Biaya operasional yang tertinggi adalah penangkapan dengan menggunakan 2 jenis alat penangkapan ikan yaitu arad dan sudu. Pengoperasian kedua jenis alat penangkapan ikan yang digunakan memerlukan daya mesin, dimana arad dengan cara menarik dan sudu dengan cara mendorong. Dengan penggunaan mesin yang secara terus-terus memerlukan bahan bakar yang lebih banyak, sehingga biaya operasional menjadi lebih tinggi. Biaya operasional yang terendah adalah pengoperasian 3 alat penangkapan ikan yaitu arad, trammel net dan gillnet. Alat penangkapan ikan gillnet yang digunakan alat alat penangkapan ikan, daya mesin hanya digunakan untuk menuju lokasi pemasangan gillnet dan kembali ke lokasi pendararan. Penggunaan alat penangkapan ikan gillnet selama 3 bulan dalam satu tahun atau tergantung musim ikan kakap. Dengan demikian total bahan bakar yang diperlukan lebih sedikit dan biaya operasional per tahun menjadi lebih rendah.
Penerimaan diperoleh dari penjualan ikan hasil tangkapan. Hasil tangkapan utama arad adalah udang krosok, cumi, rajungan, kembung dan beberapa jenis ikan lainnya. Hasil tangkapan menggunakan alat penangkapan ikan sudu yaitu udang krosok, teri dan beberapa jenis ikan lainnya. Hasil tangkapan menggunakan trammel net yaitu tigawaja, belanak dan jenis ikan lainnya. Hasil tangkapan menggunakan gillnet yaitu kakap, ekor kuning dan beberapa jenis lainnya. Total penerimaan tertinggi dalam satu tahunnya adalah nelayan dengan menggunakan 2 jenis alat penangkapan ikan yaitu Rp206.700.000. Pengoperasian arad dilakukan selama 9 bulan dan sudu selama 3 bulan. Sedangkan total penerimaan yang terendah adalah nelayan dengan mengoperasikan 3 jenis alat penangkapan ikan. Rendahnya penerimaan nelayan dengan 3 jenis alat penangkapan ikan karena waktu operasi penangkapan yang lebih sedikit. Nelayan inimelakukan operasi penangkapan ketika telah tiba musim ikan sesuai dengan jenis alat penangkapan ikan yang digunakan. Nelayan dengan menggunakan 1 alat penangkapan ikan melakukan operasional penangkapan penangkapan sepanjang tahun dan beristirahat selama 2 sampai 5 hari dalam sebulan.

Keuntungan diperoleh dari penerimaan dikurangi dengan biaya operasional dan biaya tetap. Biaya tetap terdiri dari penyusutan kapal, mesin dan penyusutan alat penangkapan ikan dalam hal ini penggantian alat penangkapan ikan. Keuntungan tertinggi diperoleh oleh nelayan dengan menggunakan 2 jenis alat penangkapan ikan. Biaya, penerimaan dan keuntungan penangkapan ikan menggunakan jumlah alat penangkapan ikan yang berbeda dapat dilihat pada Tabel 4.

Rasio penerimaan dan biaya (R/C) merupakan perbandingan total penerimaan dengan total biaya (biaya operasional dan biaya tetap). Nilai R/C yang tertinggi adalah operasional penangkapan dengan menggunakan 3 alat penangkapan ikan yaitu 1,76. Nilai ini menunjukkan bahwa dengan total biaya Rp1.000 dapat memberikan penerimaan Rp1.760. Nilai R/C dengan 1 alat penangkapan ikan pada penelitian ini lebih rendah dibandingkan nilai R/C hasil penelitian Sulistyowati (2017) yaitu 1,47 . Hal ini disebabkan karena perbedaan jumlah bahan bakar yang digunakan. Sebaliknya hasil penelitian Trisbiantoro, Hartini \& Sumaryam (2017) menunjukkan nilai R/C penangkapan menggunakan alat penangkapan ikan gillnet 
Tabel 4. Biaya, Penerimaan dan Keuntungan Berdasarkan Jumlah Alat penangkapan ikan di Jawa Tengah, 2019

Table 4. Cost, Revenue and Profit Base on Number of Fishing Gear in Central Java, 2019.

\begin{tabular}{lccc}
\hline \multirow{2}{*}{ Keterangan/Item } & \multicolumn{2}{c}{ Jenis Alat Penangkapan Ikan/ Type of Fishing Gear } \\
\cline { 2 - 4 } & Arad/Shrimp Trawl & $\begin{array}{c}\text { Arad/ Shrimp Trawl } \\
\text { dan Sudu/Trawl }\end{array}$ & $\begin{array}{c}\text { Arad/Shrimp Trawl, } \\
\text { Trammel Net dan Gillnet }\end{array}$ \\
\hline $\begin{array}{l}\text { Biaya Investasi/ } \\
\text { Investment cost }\end{array}$ & $38,000,000$ & $39,500,000$ & $40,700,000$ \\
Biaya operasional/ & $103,138,000$ & $117,258,000$ & $69,179,000$ \\
Operational cost & $140,800,000$ & $206,700,000$ & $122,000,000$ \\
Penerimaan/ Revenue & $32,362,000$ & $84,142,000$ & $47,521,000$ \\
Keuntungan/ Profit & & & \\
\hline
\end{tabular}

di Kota Surabaya adalah 2,62. Nilai R/C yang lebih tinggi dibandingkan nilai $\mathrm{R} / \mathrm{C}$ hasil penelitian ini disebabkan karena harga ikan dalam penelitian ini yang dijual lebih rendah.

Payback periode (PP) adalah waktu yang diperlukan untuk mengembalikan biaya investasi dari sejumlah keuntungan yang diterima. Nilai PP yang semakin kecil menunjukkan penggunaan waktu yang rendah untuk mengembalikan biaya investasi. Nilai $\mathrm{PP}=1$ adalah diperlukan waktu selama 1 tahun atau 12 bulan untuk dapat mengembalikan biaya investasi dari sejumlah keuntungan yang diterima. Dengan perbedaan penggunaan alat penangkapan ikan, waktu yang terlama dalam pengembalian investasi adalah operasi penangkapan menggunakan 1 jenis alat penangkapan ikan.

$\begin{array}{ccc}\text { Tingkat } & \text { pengembalian investasi } \\ \text { dari keuntungan yang diperoleh (return on }\end{array}$ investment=ROI) merupakan perbandingan keuntungan terhadap total investasi. Nilai 1 menunjukkan keuntungan dalam satu tahun dapat membayar seluruh investasi yang dikeluarkan. Nilai lebih dari satu menunjukkan bahwa keuntungan yang diperoleh dalam satu tahun lebih tinggi dari investasi yang dikeluarkan begitu juga sebaliknya. Pada penelitian ini, operasi penangkapan dengan menggunakan 1 alat penangkapan ikan diperoleh nilai ROI lebih kecil dari 1, sedangkan yang lainnya lebih dari 1. Nilai ROI ini berbanding terbalik dengan nilai PP. Nilai PP yang tinggi, maka nilai ROI akan rendah.

Nilai bersih saat ini (Net Present Value= NPV) merupakan total keuntungan selama umur proyek yang telah dikalikan dengan discount factor. Keuntungan yang akan diterima pada masa yang akan datang didiskonto menjadi nilai keuntungan saat ini, operasi penangkapan ikan dengan menggunakan 2 jenis alat penangkapan ikan memberikan nilai NPV yang paling tinggi dibandingkan dengan menggunakan 1 atau 3 alat penangkapan ikan. Tingginya nilai NPV tersebut disebabkan karena produktivitas alat penangkapan ikan sudu lebih tinggi dibandingkan trammel net dan gillnet yang dikombinasikan dalam penggunaan 3 alat penangkapan ikan. Net B/C merupakan perbandingan NPV yang bernilai positif dengan NPV bernilai negatif. Nilai NPV positif menggambarkan benefit bersih yang diperoleh, sedangkan NPV negatif menggambarkan biaya bersih yang dikeluarkan.

Interest rate of return (IRR) adalah metode perhitungan investasi dengan menghitung tingkat bunga yang menyamakan nilai sekarang investasi dengan nilai sekarang dari penerimaan-penerimaan dimasa datang. Nilai IRR usaha penangkapan ikan menggunakan alat penangkapan ikan arad dan alat penangkapan ikan pendampingnya lebih tinggi dibandingkan tingkat suku bunga yang berlaku saat ini.

Berdasarkan nilai NPV, Net B/C dan IRR menunjukkan bahwa ketiga kelompok nelayan dengan menggunakan alat penangkapan ikan arad sebagai alat penangkapan ikan utama layak untuk dijalankan. Tingkat kelayakan yang lebih tinggi adalah usaha dengan mengoperasikan 2 alat penangkapan ikan yaitu arad dan sudu. Secara ekonomi kedua alat penangkapan ikan tersebut memberikan manfaat yang lebih tinggi, tetapi dilihat dari karakteristik alat penangkapan ikan yang digunakan tidak baik untuk lingkungan. Alat penangkapan ikan arad dioperasikan dengan cara ditarik menggunakan perahu, sedangkan sudu dioperasikan dengan cara didorong. Kedua jenis alat penangkapan ikan ini tidak ramah lingkungan. Alat penangkapan ikan ikan dikatakan tidak ramah 
Tabel 5. Perbandingan Ekonomi Dengan Penggunaan 1 Alat penangkapan ikan (Arad), 2 Alat Penangkapan ikan (Arad dan Sudu) dan 3 Alat penangkapan ikan (Arad, Trammel net dan Gillnet).

Table 5. Economic Comparison With The Use of 1 Fishing Gear (Arad), 2 Fishing Gear (Arad and Sudu) and 3 Fishing Gear (Arad, Trammel net And Gillnet).

\begin{tabular}{lccc}
\hline \multirow{2}{*}{ Keterangan/ Item } & \multicolumn{3}{c}{ Jenis Alat Penangkapan Ikan / Type of Fishing Gear } \\
\cline { 2 - 4 } & $\begin{array}{c}\text { Arad/Shrimp } \\
\text { Trawl }\end{array}$ & $\begin{array}{c}\text { Arad/ Shrimp Trawl } \\
\text { dan Sudu/ Trawl }\end{array}$ & $\begin{array}{c}\text { Arad/ Shrimp Trawl, } \\
\text { Trammel Net dan Gillnet }\end{array}$ \\
\hline R/C (Revenue per cost ratio) & 1.30 & 1.69 & 1.76 \\
PP (Payback Period) & 1.17 & 0.47 & 0.86 \\
ROI (return on investment) & 0.85 & 2.13 & 1.17 \\
NPV (Net Present Value) & $101,377,450$ & $297,291,361$ & $150,037,895$ \\
Net B/C (Net Benefit-cost ratio) & 3.67 & 8.53 & 4.69 \\
IRR (Internal Rate of Return) & $94 \%$ & $225 \%$ & $123 \%$ \\
\hline
\end{tabular}

lingkungan apabila alat penangkapan ikan tersebut merusak habitat, tidak selektif, menghasilkan ikan yang bermutu rendah, alat penangkapan ikan tidak aman bagi keanekaragaman hayati, dan hasil tangkapan sampingan yang tinggi.

Usaha penangkapan ikan dengan menggunakan arad yang dikombinasikan dengan trammel net dan gillnet dapat mengurangi operasional alat penangkapan ikan arad sekaligus meningkatkan pendapatan nelayan. Pada musim ikan kakap, nelayan menggunakan gillnet yang tergolong alat penangkapan ikan ramah lingkungan. Waktu penggunaan gillnet selama 2-3 bulan dalam satu tahun. Usaha penangkapan ikan dengan hanya menggunakan alat penangkapan ikan arad saja kurang layak dibandingkan dengan menggunakan tambahan alat penangkapan ikan. Hal ini disebabkan, karena terjadi perubahan musim ikan, dan pada musim tertentu tidak efisien jika ditangkap dengan alat penangkapan ikan arad. Sejalan dengan penelitian yang dilakukan oleh Suharno \& Widayati (2016), peningkatan efisiensi penangkapan ikan menggunakan gillnet perlu penambahan input bahan bakar, input alat penangkapan ikan dan perahu. Penambahan input dilakukan untuk menjangkau fishing ground yang belum overfishing. Penelitian Laela, Nababan \& Kusumastanto (2018) menyatakan penurunan pendapatan nelayan di desa Karangreja, Cirebon karena pelarangan arad dengan menggantikan alat penangkapan ikan gillnet millenium dan bubu. Hasil analisis usaha nelayan sebelum kebijakan pelarangan arad dinilai layak akan tetapi setelah pelarangan arad usaha nelayan menjadi tidak layak. Kerugian pendapatan per trip saat mengoperasikan gillnet millenium sebesar Rp197.000/usaha/trip dan bubu sebesar Rp442.000/ usaha/trip. Usaha nelayan perikanan tangkap arad di Desa Karangreja sudah memberikan dampak ekonomi yang cukup besar bagi masyarakat disekitar Desa Karangreja, namun sebaliknya pada saat pengoperasian alat penangkapan ikan pengganti. Hal ini yang menyebabkan nelayan arad enggan beralih menggunakan alat penangkapan ikan pengganti, karena pendapatan yang diterima jauh dari sebelum pelarangan. Penelitian Nababan, Kusumastanto, Adrianto \& Fahrudin (2020b) juga menyatakan ikan-ikan demersal merupakan perikanan berumur pendek, yang jika tidak dimanfaatkan maka ikan demersal akan mengalami kematian alami. Hal ini mengakibatkan opportunity cost terhadap sumber daya ikan demersal yang artinya biaya korbanan akibat hilangnya sumber daya ikan demersal yang tidak termanfaatkan karena nelayan mengalami kerugian akibat sumber daya ikan demersal mengalami kematian alamiah karena pelarangan penangkapan dengan arad. Menurut nelayan sampai saat ini belum ada alat penangkapan ikan yang efektif menangkap ikan-ikan dasar (demersal) selain alat penangkapan ikan arad, karena alat penangkapan ikan pengganti seperti gillnet untuk menangkap ikan-ikan pelagis kecil dan bubu merupakan alat penangkapan ikan pasif yang menangkap. Penelitian ini mencoba melakukan kombinasi dari beberapa alat penangkapan ikan supaya nelayan tidak terus menerus mengoperasikan alat penangkapan ikan yang tidak ramah lingkungan seperti arad, namun juga tidak menurunkan kesejahteraan nelayan secara drastis. Hasil analisis ekonomi pada nelayan yang hanya menggunakan arad 
saja sepanjang tahun maka kesejahteraannya lebih rendah jika dibandingkan dengan melakukan kombinasi menggunakan arad, trammelnet / gillnet. Penggunaan arad hanya dilakukan pada musim banyaknya ikan-ikan demersal dan beralih menggunakan alat penangkapan ikan tramelnet / gillnet saat musim ikan pelagis atau menurunnya tangkapan ikan demersal. Hal ini merupakan trade off kebijakan, dimana jika pelarangan secara penuh maka pelaksanaan kebijakan tersebut tidak akan berjalan karena tidak ada nelayan yang mengalami penurunan kesejahteraan. Para nelayan lebih setuju dengan pembatasan alat penangkapan ikan arad bukan dengan pelarangan. Pembatasan ini yaitu alat penangkapan ikan arad tetap diijinkan beroperasi pada saat musim ikan demersal dan menggunakan alat penangkapan ikan yang ramah lingkungan (tramelnet/gillnet) pada saat musim ikan pelagis.

\section{KESIMPULAN DAN REKOMENDASI KEBIJAKAN}

\section{Kesimpulan}

Komposisi ikan hasil tangkapan nelayan menggunakan alat penangkapan ikan arad di Jawa Tengah mengalami perubahan, yang semula menangkap udang dan ikan demersal menjadi menangkap ikan demersal dan ikan pelagis kecil. Penangkapan ikan dengan hanya menggunakan jaring arad sepanjang tahun memberikan manfaat ekonomi yang lebih rendah dibandingkan menggunakan beberapa jenis alat penangkapan ikan. Dalam upaya meningkatkan hasil tangkapan ikan, nelayan arad membeli alat penangkapan ikan lain seperti sudu. Secara ekonomi, manfaat yang diterima oleh nelayan dengan 2 jenis alat penangkapan ikan (arad dan sudu) paling tinggi, namun secara ekologi, kedua alat penangkapan ikan tersebut merupakan alat penangkapan ikan pukat tarik dan pukat hela yang tidak ramah lingkungan (jenis alat penangkapan ikan yang dilarang berdasarkan Permen KP no 2 tahun 2015).

Nelayan yang menggunakan alat penangkapan ikan arad, trammel net dan gillnet (kombinasi 3 alat penangkapan ikan) memperoleh manfaat ekonomi yang lebih tinggi dibandingkan nelayan yang hanya memiliki arad saja. Hal ini disebabkan karena penggunaan biaya operasional yang lebih rendah. Nelayan yang menggunakan ketiga alat ini menggunakan jenis alat penangkapan ikan sesuai dengan musim ikan: saat musim kakap dan kembung maka nelayan menggunakan gillnet, saat musim belanak dan tigawaja maka nelayan menggunakan trammel net, dan saat musim rebon, cumi dan teri maka nelayan menggunakan arad. Kendala yang dihadapi oleh nelayan dengan 3 jenis alat penangkapan ikan ini adalah tingginya biaya investasi untuk pembelian alat penangkapan ikan. Kombinasi ketiga alat ini (arad, gillnet dan trammel net) mengurangi dampak penangkapan oleh arad setiap musim sepanjang tahun.

\section{Rekomendasi Kebijakan}

Pukat tarik berdasarkan PerMen KP 71/2016 terkategori dilarang namun pada kenyataannya di lapang sampai saat ini masih beroperasi. Permasalahan sehingga pelarangan arad tidak dapat dilaksanakan oleh nelayan karena menurunnya kesejahteraan nelayan. Penelitian ini mencoba melakukan kombinasi dari beberapa alat penangkapan ikan supaya nelayan tidak terus menerus mengoperasikan alat penangkapan ikan yang tidak ramah lingkungan seperti arad, namun juga tidak menurunkan kesejahteraan nelayan secara drastis. Hasil analisis ekonomi pada nelayan yang hanya menggunakan arad saja sepanjang tahun maka kesejahteraannya lebih rendah jika dibandingkan dengan melakukan kombinasi menggunakan arad, gillnet dan trammelnet. Hal ini merupakan trade off kebijakan, dimana jika pelarangan secara penuh maka pelaksanaan kebijakan tersebut tidak akan berjalan karena tidak ada nelayan yang bersedia mengalami penurunan kesejahteraan. Dalam hal ini, pelarangan alat penangkapan ikan sepenuhnya bukan menjadi solusi karena akan meningkatkan kelestarian ikan namun akan menurunkan kesejahteraan nelayan. Nelayan lebih setuju dengan pembatasan yang akan menjembatani kelestarian dan kesejahteraan. Nelayan dengan menggunakan alat penangkapan ikan arad yang dikombinasikan dengan alat penangkapan ikan gillnet / trammel net memperoleh manfaat ekonomi yang lebih tinggi sekaligus lebih ramah lingkungan. Dalam hal ini, nelayan dapat mengurangi intensitas penangkapan menggunakan arad dengan mengganti penggunaan gillnet/ trammel net pada musim penangkapan tertentu dengan biaya operasional yang lebih murah dan ikan hasil tangkapan bernilai lebih tinggi. Kombinasi penggunaan alat penangkapan ikan ini akan menjadi titik tengah antara kelestarian sumber daya ikan dan kesejahteraan nelayan. 


\section{UCAPAN TERIMA KASIH}

Terima kasih saya sampaikan kepada Redaksi Jurnal Sosial Ekonomi Kelautan dan Perikanan karena telah memberikan kesempatan untuk penerbitan naskah ini, kepada Conservation Strategic Fund (CSF Indonesia) yang telah memberikan dukungan untuk pelaksanaan penelitian.

\section{PERNYATAAN KONTRIBUSI PENULIS}

Semua penulis mendiskusikan hasil dan berkontribusi dari awal hingga akhir naskah; Kontributor utama pada naskah ini adalah Benny Osta Nababan yang bertugas melakukan survei data, pengolaham data. Kontributor anggota adalah Tridoyo Kusumastanto, Luky Adrianto, dan Achmad Fahrudin merupakan komisi pembimbing yang mengarahkan dan memberikan saran untuk perbaikan substansi artikel jurnal.

\section{DAFTAR PUSTAKA}

Balton, D.A. (2004). "Global Review of Illegal, Unreported and Unregulated Fishing Issues: What's the Problem?". Programme for the Workshop on IUU Fishing Activities, FAO, Paris, 19-20 April 2004.

Budiman. (2006). Analisis Sebaran Ikan Demersal Sebagai Basis Pengelolaan Sumber daya Pesisir di Kabupaten Kendal. Tesis. Program Pasca Sarjana. Universitas Diponegoro. Seamrang.

Diniah. (2008). Pengenalan Perikanan Tangkap. Departemen Pemanfaatan Sumber daya Perikanan Fakultas Perikanan dan Kelautan. FPIK. Institut Pertanian Bogor. Bogor.

[DKP] Dinas Kelautan dan Perikanan Jawa Tengah. (2017). Rencana Strategis Dinas Kelautan dan Perikanan Provinsi Jawa Tengah 2013 - 2018.

Ernawati. T. (2007). Distribusi dan Komposisi Jenis Ikan Demersal Yang Tertangkap Trawl Pada Musim Barat Di Perairan Utara Jawa Tengah. Jurnal Ikhtiologi Indonesia, Volume 7 No 1 Tahun 2007. doi.org/10.32491/jii.v7i1.222

Ernawati, T \& Sumiono, B. (2010). Hasil Tangkapan Dan Laju Tangkap Jaring Arad (Mini Bottom Trawl) yang Berbasis di TPI Asemdoyong Pemalang. Jurnal Penelitian Perikanan Indonesia, Vol.16 No.4 Desember 2010. DOI.org/10.15578/ jppi.16.4.2010.267-274.

Ermawati, N. \& Zuliyati. (2015). Dampak Sosial Dan Ekonomi Atas Peraturan Menteri Kelautan dan Perikanan Nomor 2/PERMEN-KP/2015 (Studi Kasus Kecamatan Juwana Kabupaten Pati). Proceeding SENDI_U. Prosiding Seminar Nasional Multi Disiplin IImu \& Call For Papers
Unisbank. Kajian Multi Disiplin IImu untuk Mewujudkan Poros Maritim dalam Pembangunan Ekonomi Berbasis Kesejahteraan Rakyat ISBN: 978-979-3649-81-8.

Fauzi A. \& Anna S. (2010). The Java Sea Small-Scale Fisheries in Changing Environment: Experiences From Indonesia. France (FR): IFET Montpellier Pr.Gittinger, J.P. (1986). Analisa Ekonomi Proyek-Proyek Pertanian. Terjemahan. Edisi Kedua. UI-Press dan John Hopkins. Jakarta.

Haynes, J., Geen G. \& Wilks L. (1986) Beneficiaries of Fisheries Management. Discussion paper 86.1, Bureau of Agricultural Economics, Australian Government Publishing Service, Canberra.

Hedianto, D.A, Purnamaningtyas, S.E \& Riswanto. (2014). Sebaran dan Habitat Juvenil Udang Penaeid di Perairan Kubu Raya, Kalimantan Barat. BAWAL, Vol. 6 (2) Agustus 2014. DOI.org/10.15578/jppi.23.3.2017.153-166

Indrawasih R. \& Wahyono, A. (2009). Pengoperasian Jaring Arad Di Perairan Pantai Utara Jawa: Masalah dan Penyelesaiannya. Jurnal Kebijakan dan Riset Sosial Ekonomi Kelautan dan Perikanan, volume 4 No 1, 2009. DOl.org/10.15578/jsekp. v4i1.5821.

[KKP] Kementerian Kelautan dan Perikanan. (2013). Profil Kelautan dan Perikanan Provinsi Jawa Tengah untuk Mendukung Industrial Kelautan dan Perikanan. Pusat Data Statistik dan Informasi, Sekretariat Jenderal Kementerian Kelautan dan Perikanan.

[KKP] Kementerian Kelautan dan Perikanan. (2015). Peraturan Menteri Kelautan Dan Perikanan Nomor 02/Permen-Kp/2015 Tentang Larangan Penggunaan Alat Penangkapan Ikan Pukat Hela (Trawls) Dan Pukat Tarik (Seine Nets) Di Wilayah Pengelolaan Perikanan Negara Republik Indonesia.

[KKP] Kementerian Kelautan dan Perikanan. (2016). Keputusan Menteri Kelautan dan Perikanan No. 47/Kepm-KP/2016. Kementerian Kelautan dan Perikanan Republik Indonesia. Jakarta

[KKP] Kementerian Kelautan dan Perikanan. (2016). Peraturan Menteri Kelautan Dan Perikanan Republik Indonesia Nomor 71/Permen-Kp/ 2016 Tentang Jalur Penangkapan Ikan dan Penempatan Alat Penangkapan Ikan Di Wilayah Pengelolaan Perikanan Negara Republik Indonesia.

Laela, E. N., Nababan, B. O., Kusumastanto, T. (2018). Analisis Dampak Ekonomi Kebijakan Pelarangan Arad Di Desa Karangreja Cirebon. Departemen Ekonomi Sumber daya dan Lingkungan. Fakultas Ekonomi dan Manajemen. IPB University.

Mc Elroy J. (1991a). The Java Sea Purse Seine Fishery: A Modern Day "Tragedy of The Common". Marine Policy. 
Mc Elroy J. (1991b). Managing the Indonesian Small Pelagic Fishery. Marine Policy.

Merta, I.G.S., Widodo, J \& Nurhakim, S. (1999). Sumber daya Ikan Pelagis. Buku II. Ditjen Perikanan Departemen Pertanian, Jakarta.

Nababan, B. O., Solihin, A. \& Christian, Y. (2018). Dampak Sosial Ekonomi Kebijakan Larangan Pukat Hela dan Pukat Tarik d Pantai Utara Jawa. Indonesia Marine Fellows. Conservation Strategy Fund.

Nababan, B. O., Kusumastanto, T., Adrianto, L. \& Fahrudin, A. (2020a). The economic impact of the "cantrang" prohibition in the northern Java Sea, Indonesia. AACL Bioflux 13(2):705-714 April 2020. AACL Bioflux - International Journal Online ISSN: 1844-9166.

Nababan, B. O., Kusumastanto, T., Adrianto, L., Fahrudin, A. (2020b). Model Ekonomi Kesejahteraan Nelayan Perikanan Tangkap (Studi Kasus Multispecies dan Multigear). Disertasi. Program Studi Ekonomi Kelautan Tropika. Fakultas Ekonomi dan Manajemen. Sekolah Pascasarjana IPB. IPB University.

Naya, D. A. B., Wijayanto, D., Sardiyatmo. (2017). Analisis Komoditas Unggulan Perikanan Tangkap Di Provinsi Jawa Tengah. Journal of Fisheries Resources Utilization Management and Technology. Vol. 6, Nomor 3, Tahun 2017, HIm 37-46.

Rees, J. A. (1990). Natural Resources: Allocation, Economics and Policy. Routledge, Chapman \& Hall, Incorporated.

Rowandi, W. (2011). Kajian Teknis Dan Legalitas Jaring Arad Di Perairan Utara Kabupaten Subang Jawa Barat. Skripsi. Institut Pertanian Bogor.

Septiana, E, Saputra, S. W \& Ghofur, A. (2019). Analisis Hasil Tangkapan Jaring Arad di Pangkalan Pendaratan Ikan (PPI) Tambak Lorok, Semarang. Saintek Perikanan, Vol. 14 No 2 tahun 2019.

Suharno \& Widayati, T. (2016). Kebijakan Pengelolaan Usaha Perikanan Tangkap Nelayan Skala Kecil di Pantura Jawa Tengah. Prosiding Seminar Nasional Multi Disiplin IImu \& Call For Papers Unisbank (Sendi_U).

Sukandar, Raka, D.G., Setyohadi, D., Sambah, A.B., Bintoro, G., Darmawan, Ika, L. \& Fuad. (2015). Tinjauan Akademis terhadap Permen KP No.2/Permen-KP/2015.BPP-FPIK Universitas Brawijaya. Malang.

Sulistyowati. (2017). Analisis Tingkat Efisiensi penangkapan dengan Jaring Arad di kabupaten Batang. Jurnal Dinamika Sosial Ekonomi, Volume 6 No 12017.
[SDG] Sustainable Development Goal. (2019). Sustainable Development Goal 14 Conserve and sustainably use the oceans, seas and marine resources for sustainable development. Retrieved from https://sustainabledevelopment. un.org/sdg14.

Triarso, I. (2012). Potensi dan Peluang Pengembangan Usah Perikanan Tangkap di Pantura Jawa Tengah. Jurnal Saintek Perikanan, Volume 8 No 1 tahun 2012.

Triharyuni, S \& Trihargiyatno, I. (2012). Model Produksi Jaring Arad di pantai Utara Jawa yang berbasis di Pekalongan. Jurnal Penelitian Perikanan Indonesia, Vol.18 No. 4 Desember 2012. DOI. org/10.15578/jppi.18.4.2012.213-219.

Trisbiantoro, D. Hartini, S. S. \& Sumaryam. (2017). Analisa Pola Pembiayaan Usaha Penangkapan Ikan dengan Menggunakan Alat Tangkap Jaring Insang (Gill net) dengan Bulak Kota Surabaya. Prosiding Seminar Nasional Kelautan dan Perikanan III 2017.

Trisbiantoro, D., Hartini, S. S., \& Sumaryam. (2017). Analisa Pola Pembiayaan Usaha Penangkapan Ikan Dengan Menggunakan Alat Tangkap Jaring Insang (Gillnet) Nelayan Bulak Kota Surabaya. Prosiding Seminar Nasional Kelautan dan Perikanan III Tahun 2017. Universitas Trunojoyo Madura, 7 September 2017.

Xue, G. (2003). China and International Fisheries Law and Policy. Martinus Nijhof Publisher, Cambridge-UK. 